\title{
THE POTENTIAL FOR OVERSOWING; LUCERNE ON STEEPLAND SOILS IN NORTH AND CENTRAL OTAGO
}

\author{
D. J. Musgrave*, R. J. Claret and W. L. Lowtherł
}

\section{Abstract}

A summary of results is given from trials investigating the effect of sowing date, lime, altitude, aspect and seed treatment on the establishment and production of oversown lucerne at various sites in the semi-arid to sub-humid zones of North and Central Otago. Spring sowings were generally more successful in establishing lucerne than autumn sowings. Early to mid-August sowings appeared more satisfactory on low altitude sunny country, while colder, shady aspect country responded to slightly later sowings. Higher numbers of plants established at the higher altitudes. Lime pelleting and heavy inoculation rates increased lucerne establishment when favourable environmental conditions followed sowing, but did not ensure establishment under adverse conditions. At $\mathrm{pH} 6.2$ to 6.6 , there was no consistent response in lucerne establishment to 1200 $\mathrm{kg} / \mathrm{ha}$ lime, although up to $60 \%$ increases in establishment were obtained on some sites. Herbage yields of over 5 t/ha dry matter were recorded on the best plots, at lucerne plant densities in excess of 10 to $20 / \mathrm{m}^{2}$. With present techniques, oversowing of lucerne in this environment is not recommended, except on damper sites, as satisfactory lucerne establishment has not been achieved consistently in trial work.

\section{INTRODUCTION}

IN RECENT YEARS there has been considerable interest in the use of lucerne as an alternative legume to clovers for the improvement of tussock grasslands in the semi-arid to sub-humid zones of the South Island. Janson and White (1971), Nixon (1971) and White (1970) in the sub-humid zone and Douglas (1974) in the semi-arid zone have demonstrated the feasibility of establishing lucerne by oversowing under some conditions. Douglas (1974), using heavily inoculated seed, obtained satisfactory establishment from both April and July/August sowings, although lime

* Tara Hills High Country Research Station, MAF, Omarama.

J-Soil and Field Research, MAF, Alexandra.

† Invermay Agricultural Research Centre, MAF, Mosgiel. 
pelleting gave little improvement in establishment. Other workers have shown the importance of both pelleting and heavy inoculation for the establishment of lucerne (Brockwell and Phillips, 1970) and clover (Lowther and McDonald, 1973) sown in difficult conditions.

The 66 trials summarized in this paper examined the effects of sowing date, lime usage and seed treatment on the establishment of lucerne by oversowing over a wide range of conditions in the semi-arid to sub-humid zones of North and Central Otago from 1970 to 1973 .

\section{EXPERIMENTAL}

The sites ranged in altitude from 200 to $1100 \mathrm{~m}$ and were within the 400 to $650 \mathrm{~mm}$ mean anaual rainfall zone, with the majority receiving less than $500 \mathrm{~mm}$ per annum. Rainfall was reflected to some extent by the vegetation present, with the damper sites having a denser tussock cover. The main grasses present were fescue tussock (Festuca novae-zelancliue) with silver tussock (Poa laevis) and annual grasses (Aira and Bromus spp.); the predominant associated species were sheep's sorrel (Rumex acetosella), haresfoot trefoil (Trifolium arvense) and storksbill (Erodium cicutarium). Scabweed (Raoulia spp.) was also present on the drier sites. The trials were four-replicate, split-plot or fully randomized block designs with $2 \times 3 \mathrm{~m}$ plots.

The soils were all naturally fertile and well suited for lucerne except for sulphur deficiency, which was corrected by a basal application equivalent to 120 to $200 \mathrm{~kg} / \mathrm{ha}$ molybdic sulphur superphosphate (18\% elemental sulphur) broadcast before sowing. The Central Otago trials were sown with $10 \mathrm{~kg} / \mathrm{ha}$ of Wairau lucerne seed commercially inoculated and lime pelleted (Prillcote). The North Otago trials were sown with $11 \mathrm{~kg} / \mathrm{ha}$ seed inoculated with commercial cultures and, where pelleted, gum arabic/lime pellets prepared by the method of Hastings and Drake (1963) were used. The seed was broadcast on to the existing turf, which had previously been open to grazing.

Germination counts, when taken, were a mean of ten throws of a $15 \mathrm{~cm}$ square quadrat. Total numbers of established plants were counted not less than six months after sowing. In their second season, selected plots at $475 \mathrm{~m}$ on a sunny face at Omarama were cut five times at the $10 \%$ bloom stage to measure herbage yield. Analysis of variance was performed on square root transformed establishment data from North Otago trials, but no analysis was performed on Central Otago results. 


\title{
RESULTS AND DISCUSSION
}

\author{
Sowing Date AND Site Factors
}

Over all the trials in this present work, autumn sowings were generally inferior to spring sowings in establishing lucerne (Table i). This was contrary to the results obtained by Douglas (1974) in other seasons. Hbwever, the most satisfactory month for oversowing was influenced by altitude and aspect.

TABLE 1: THE EFFECT OF SOWING DATE ON LUCERNE ESTABLISHMENT

(Means of all trials)

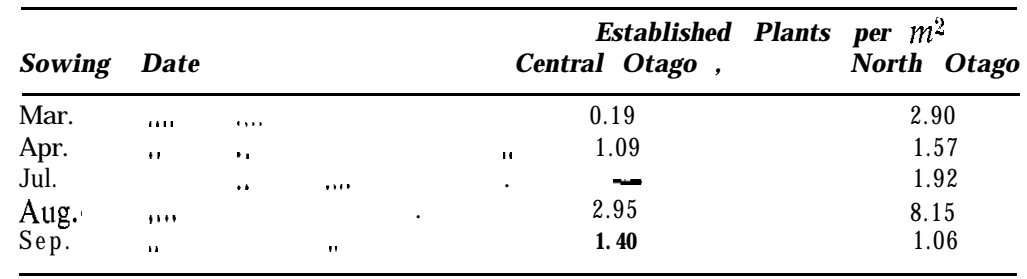

In a study in North Otago at $475 \mathrm{~m}$ altitude, on both a sunny and shady aspect the early September sowing gave the highest percentage of 'seedlings establishing to the unifoliate leaf stage (Table 2). The percentages of seedlings establishing to the unifoliate leaf Stage closely reflected the rising temperatures rather than the rainfall pattern. However, the final number of plants establishing fdllowed different patterns, with the August sowing giving maximum numbers on the sunny aspect. On the shady aspect, maximum numbers established from the September sowing. It is likely that an earlier onset of unfavourable temperature and moisture conditions on the sunny face restricted- the number of seedlings becoming nodulated and surviving.

These results and results from altitude comparisons suggest that best establishment on low altitude sunny faces is obtained from early to mid-August sowings. On shadier or higher altitude sites, similar favourable temperature-moisture regimes suitable for maximum establishment do not occur until slightly later.

A major influence of rainfall on establishment was apparent (Table 3), the great variability causing big fluctuations in the number of plants establishing from year to year. As rainfall is both uncontrollable and unpredictable (monthly totals at Tara Hills have a CV as high as 95\%) it is not possible to guarantee success of lucerne oversowing in this area. Further research on sowing date of oversown lucerne should attempt to relate estab- 
TABLE 2: THE EFFECT OF SOWING DATE AND ASPECT ON SEEDLINGS REACHING THE UNIFOLIATE LEAF STAGE AND FINAL PLANT ESTABLISHMENT

$$
\text { (Omarama Station, } 475 \mathrm{~m} \text { altitude) }
$$

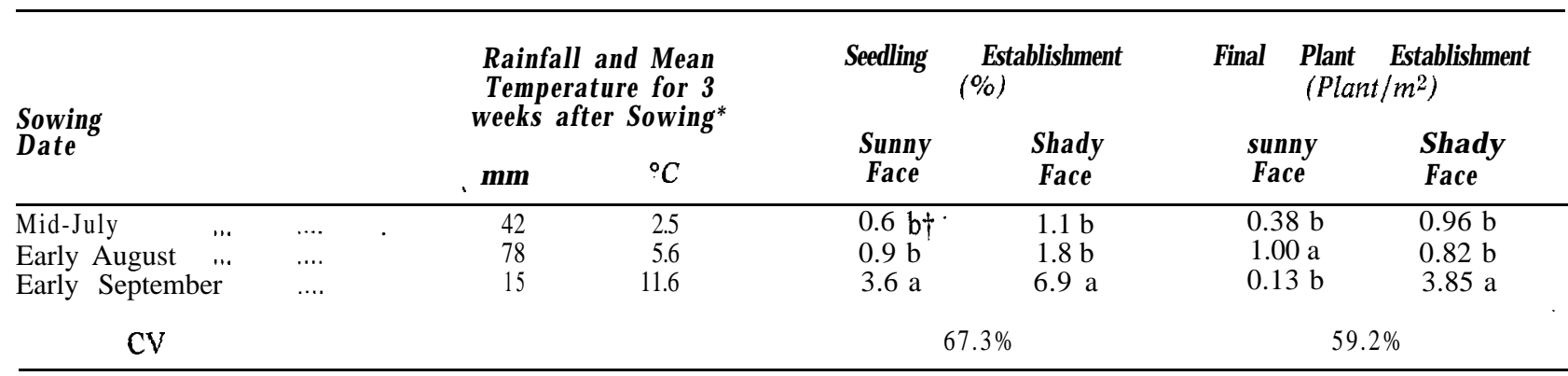

* Mean of the two sites.

$\dagger$ Means within a column without a common Ietter differ significantly (lower case, $P<0.05$; upper case, $P<0.01$ ). 
TABLE 3: THE EFFECT OF SEASONAL DIFFERENCES ON LUCERNE ESTABLISHMENT ON A SHADY FACE AT OMARAMA STATION

\begin{tabular}{|c|c|c|c|c|c|c|c|}
\hline & & & & $\begin{array}{l}\text { Rainfall } \\
\text { after S }\end{array}$ & $\begin{array}{l}3 \text { weeks } \\
g(\mathrm{~mm})\end{array}$ & $\begin{array}{r}\text { Establis } \\
p\end{array}$ & $2^{\text {Plants }}$ \\
\hline & & & & & & & Aug. \\
\hline 1972 & & & & 59 & 94 & $4.9 \mathrm{~b}$ & $15.9 \mathrm{a}$ \\
\hline 1973 & & & & 28 & 15 & $0.6 \mathrm{c}$ & $4.0 \mathrm{~b}$ \\
\hline c & V & . & .,. & & & & \\
\hline
\end{tabular}

lishment to relatively easily made measurements such as soil temperatures and/or soil moisture, so that, for any given rainfall following sowing, seedling establishment and nodulation of these seedlings will be maximized.

An altitudinal sequence in Central Otago showed increasing numbers of plants establishing with altitude (Table 4), although there were some indications of a fall off in numbers at the higher altitudes.

TABLE 4: THE EFFECT OF ALTITUDE ON LUCERNE ESTABLISHMENT

(Mean of 12 trials in Central Otago)

\begin{tabular}{cc}
\hline Altitude $(\boldsymbol{m})$ & Established Plants per $\mathbf{m}^{\mathbf{2}}$ \\
\hline 200 & 0.08 \\
290 & 0.25 \\
670 & 2.35 \\
790 & 3.58 \\
940 & 1.77 \\
1100 & 2.74 \\
\hline
\end{tabular}

LIME

Most of the sites in Central Otago were in the $\mathrm{pH}$ range 6.2 to 6.6, and, although there was no consistent effect of 1200 $\mathrm{kg} / \mathrm{ha}$ lime on the establishment of lucerne, increases of up to $60 \%$ in the final number of plants establishing were obtained on some sites from the application of lime at sowing. Douglas (1974), in North Otago trials, obtained similar small responses to 375 and $630 \mathrm{~kg} / \mathrm{ha}$ of lime on sites with $\mathrm{pH} 6.2$ to 6.6. This suggests that further investigation of the use of small amounts of lime on these higher $\mathrm{pH}$ soils may be warranted.

On two sites with $\mathrm{pH} 5.4$ and 5.6, the final numbers of plants establishing were increased by between 120 and $180 \%$ from the use of lime. 
SeEd Treatments

Increases in the number of lucerne plants establishing from oversowing can be expected from treatments that improve the number of seedlings which become successfully nodulated. With favourable sowing conditions, the responses obtained to lime pelleting (Table 5) and high inoculation rates (Tables 5 and 6) were very marked, although, in contrast to the results of Taylor and Lloyd (1968) with clover, the additional peat layer did not improve nodulation. Under unfavourable conditions, such as the late March sowing, none of the seed treatments used were able to ensure nodulation and establishment of the plants.

The use of some form of pellet to protect the rhizobia on the seed from the unfavourable environmental conditions appears the most practical method of improving the nodulation phase of the establishment process. Although expensive, inoculation at very high rates would be justified if it ensured nodulation, but unfortunately this is not so and future research must attempt to develop other seed treatments that will ensure nodulation under the most rigorous conditions.

TABLE 5: THE EFFECT OF SEED TREATMENTS AND SOWING DATE ON LUCERNE ESTABLISHMENT (Mean of 3 North Otago trials)

\begin{tabular}{|c|c|c|}
\hline \multirow[b]{2}{*}{ Seed Treatment } & \multicolumn{2}{|c|}{ Established Plants per $\mathrm{m}^{2}$} \\
\hline & Late $M$ ar. & Late A ug. \\
\hline 5 Normal (N) inoculation & $0.6 \mathrm{a}$ & $7.6 \mathrm{cC}$ \\
\hline $\begin{array}{l}\text { No pellet } \\
5 \mathrm{~N} \text { inoculation } . "\end{array}$ & $1.6 \mathrm{a}$ & $21.8 \mathrm{bB}$ \\
\hline Lime pellet & & \\
\hline $\begin{array}{l}5 \mathrm{~N} \text { inoculation } \\
\text { Lime + peat pellet }\end{array}$ & $1.3 \mathrm{a}$ & 24.9 bB \\
\hline $\begin{array}{l}50 \mathrm{~N} \text { inoculation } \\
\text { Lime pellet }\end{array}$ & $1.3 \mathrm{a}$ & 33.6 aA \\
\hline $\mathrm{c} \mathrm{v}$ & \multicolumn{2}{|c|}{$29.9 \%$} \\
\hline
\end{tabular}

TABLE 6: THE EFFECT OF LEVEL OF INOCULATION ON LUCERNE ESTABLISHMENT

, (Mean of 7 North Otago trials)

\begin{tabular}{|c|c|c|c|c|c|c|c|}
\hline Inoculation Level & & & & & & & $\begin{array}{l}\text { ablished Plants } \\
\text { per } m^{2}\end{array}$ \\
\hline 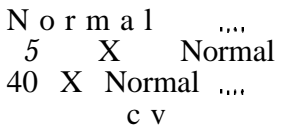 & $\begin{array}{l}\quad \cdots+1 \\
\because \cdots \\
\cdots\end{array}$ & $\cdots$ & $\begin{array}{l}\cdots \cdot \cdot \\
\cdots \cdot\end{array}$ & $\cdots$ & $\begin{array}{l}\cdots \cdot \cdot \\
\cdots \cdot\end{array}$ & $\begin{array}{l}\cdots \cdot \\
\cdots \cdot \cdot \\
\cdots \\
\cdots\end{array}$ & $\begin{array}{l}3.06 \mathrm{c} \\
4.00 \mathrm{~b} \\
4.50 \mathrm{a} \\
59.2 \%\end{array}$ \\
\hline
\end{tabular}




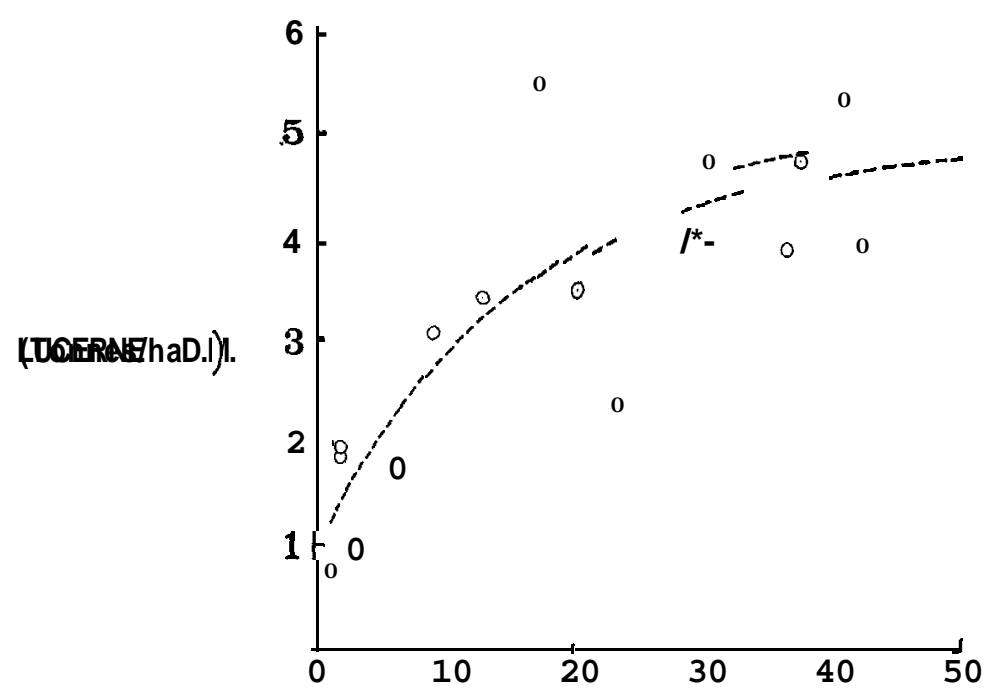

\section{NUMBER OF' PLANTS/m2}

FIG. 1: Relationship between lucerne plant densities and Lucerne dry matter production over the 1973-4 season on a sunny face on Omarama station.

\section{Dry Matter Production}

The potential production from established oversown lucerne appears to be very high (Fig. 1). The best plots at $475 \mathrm{~m}$ on a sunny face at Omarama produced over 5 t/ha of dry matter in their second season. However, plant densities of greater than 10 to 20 plants/m" appear to be necessary for the plants to approach full utilization of this environment. This compares more than favourably with the production of $0.1 \mathrm{t} / \mathrm{ha}$ measured from the resident vegetation at the same site.

The mean production over the 1973-4 season for those plots with more than 10 plants $/ \mathrm{m}^{2}$ was $4.1 \mathrm{t} / \mathrm{ha}$, while production from dryland lucerne stands cut for hay at the adjacent Tara Hills High Country Research Station was 4.9 t/ha.

The usefulness of lucerne is not necessarily confined to lower sites, as, in spite of slow establishment on a sunny face at $1070 \mathrm{~m}$, lucerne has yielded as much as white clover (Musgrave, unpublished data), this in what is regarded as white clover's domain. 
Once lucerne is established, its benefits to farming in these semiarid areas are likely to be great. Lunn and Smetham (1966) estimated that the dry steepland soils of Central Otago were carrying between 0.06 and 0.16 stock units (s.u.) per hectare, with a potential to improve to between 0.1 and OS s.u./ha by spelling to encourage native grasses and by limited oversowing. With lucerne oversowing the carrying capacity is more likely to be at least 3 to $4 \mathrm{s.u}$./ha and, when combined with ryegrass and cocksfoot, should do much to overcome the problems of low production in the critical July-September period (Snow, 1966).

\section{CONCLUSION}

With our present state of knowledge, establishment of lucerne by oversowing cannot be guaranteed on the very dry, low altitude sunny faces where lucerne is most likely to have the biggest agronomic advantage over clovers. Satisfactory establishment of lucerne plants has been achieved on 'relatively few occasions in trial work and then only on the damper sites or following timely heavy falls of rain.

\section{ACKNOWLEDGEMENTS}

The authors would like to thank the following: Coated Seed Ltd for pelleting seed; T. R. Wallis, J. E. Thorley and T. E. Williams for field assistance; and R. T. Wardell, R. M. Snow, B. B. Waldron, J. F. Cameron, W. J. Whalan, J. Revelly, H. Gloag and M. F. Mulvena for their interest in allowing trial sites on their properties.

\section{REFERENCES}

Brockwell, J.; Phillips, L. J., 1970. Aust. J. exp. Agric. Anim. Husb. 10: 739-44.

Douglas, J. A., 1974. Proc, 12th int. Grassld Congr.: 100-9.

Hastings, A.; Drake, A. D., 1963. N.Z. Il Agric., 106: 463-8.

Janson, C. G.; White, J. G. H., 1971. N.Z. Il ngric. Res., 14: 572-86.

Lowther, W. L.; McDonald, I. R., 1973. N.Z. Il exp. Agric., 1: 175-9.

Lunn W. A.; Smetham, M. L., 1966. Proc. N.Z. Grassld Ass., 28: 27-39.

Nixon, G. W., 1971. Proc. N.Z. Agron. Soc., 1: 95101.

Snow, R. M., 1966. Proc. N.Z. Grassld Ass., 28: 140-6.

Taylor, G. G.; Lloyd, J. M., 1968. Proc. N.Z. Grassld Ass., 30: 154-63.

White, J. G. H., 1970. Proc, 11th int. G rassld Congr.: 134-8. 